\title{
RSM Optimization for the Recovery of Technofunctional Protein Extracts from Porcine Hearts
}

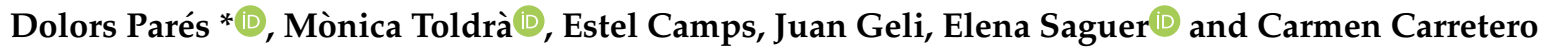 \\ Institute for Food and Agricultural Technology (INTEA), University of Girona, Escola Politècnica \\ Superior (EPS-1), C/Maria Aurèlia Capmany 61, 17003 Girona, Spain; monica.toldra@udg.edu (M.T.); \\ estelcamps2@gmail.com (E.C.); juangeli97@gmail.com (J.G.); elena.saguer@udg.edu (E.S.); \\ carmen.carretero@udg.edu (C.C.) \\ * Correspondence: dolors.pares@udg.edu; Tel.: +34-972-418-347
}

Received: 2 November 2020; Accepted: 20 November 2020; Published: 25 November 2020

\begin{abstract}
Meat byproducts, such as the internal organs from slaughtered animals, are usually underutilized materials with low commercial value. The functional (emulsifying, gelling, and foaming) properties of soluble protein extracts derived from pork hearts were investigated, as well as their molecular weight distribution. A central composite design (CCD) for two process variables ( $\mathrm{pH}$ and ionic strength of the extraction buffer) was used to foreknow the effects of the process conditions on the physicochemical characteristics and technofunctionality of the protein extracts by means of the response surface methodology (RSM). SDS-PAGE patterns of the heart protein solutions revealed multiple bands with molecular weights ranging from 15 to $220 \mathrm{kDa}$, mainly corresponding to sarcoplasmic, myofibrillar, as well as blood proteins. The best extraction conditions to obtain protein fractions with good foaming properties would correspond to acid $\mathrm{pH}(\mathrm{pH} \leq 5)$ and high salt content $(2-4 \%)$. On the contrary, solutions recovered at $\mathrm{pH}>5$ with low $\mathrm{NaCl}$ contents were the ones showing better emulsifying properties. Regarding gelation ability, heat-induced gels were obtained from extracts at $\mathrm{pH}$ 6.5-8, which showed improved firmness with increasing $\mathrm{NaCl}$ content $(2-4 \%)$. Satisfactory second-order polynomial models were obtained for all the studied response variables, which can be useful in guiding the development of functional ingredients tailored for specific uses to maximize applications.
\end{abstract}

Keywords: meat byproducts; porcine heart; protein extraction; response surface methodology; technofunctional properties

\section{Introduction}

Efficient utilization of meat byproducts such as blood and offal is important for the profitability of the meat industry. It has been estimated that significant percentages of the gross income from food-producing animals come from these byproducts, about $11.4 \%$ and $7.5 \%$ from beef and pork, respectively [1]. Most byproducts have good nutritive value and can be utilized for food, to a greater or lesser degree depending on traditions, culture, and religion, as well as regulatory requirements. Traditional markets for edible meat byproducts have gradually decreased because of quality and health preoccupations; which have led to an increased focus on nonfood uses, such as pet foods, animal feed, pharmaceuticals and cosmetics [1,2], fertilizers, and biodiesel generation sources [3].

Currently, maximizing the use of animal proteins in the food industry is a crucial challenge due to the exponential increase in the meat protein demand and because of environmental concerns related to the meat chain. Thus, it is highly advisable to consider all byproducts as raw materials that can be changed into valuable food products or ingredients [4-6]. Such added value can be obtained in terms of shelf stability, more convenience, better sensory quality, and also improved technological functions, 
which can lead to the development of flavoring ingredients, water bonding agents, and stabilizers or emulsifiers [3].

Various categories of nonmeat technofunctional ingredients as such are chemicals, like sodium chloride, phosphates, carbonates and citrates; hydrocolloids, starches, flours, and vegetable fibers; or proteins like vegetable, dairy, and egg proteins; are used by meat processors to achieve different technological requirements and to meet consumer expectations. Some of these ingredients can be considered problematic to reach clean-label purposes or even may pose health concerns because they are catalogued as allergens. Thus, the development of alternative functional ingredients of meat origin can be a smart way to solve both aspects.

Meat byproducts can be a valuable source of technofunctional ingredients [2,6-12]. Among them, internal animal organs such are liver, lungs, brain, spleen, or heart, usually are low commercial valued and underutilized materials. Since they contain varying amounts of myofibrillar, sarcoplasmic, and stromal proteins when compared with those of lean meat $[2,13,14]$, differences in the behavior of protein fractions from these byproducts when heated, as well as in the role of salts and $\mathrm{pH}$ on water holding capacity and texture, are conceivable. In this context, more information on the functional properties of protein fractions of meat byproducts can be useful for food processors.

The present work focuses on obtaining protein extracts from porcine hearts. Some studies on this topic can be found in the recent literature. Kim et al. (2017) tested the use of ultrasound-assisted extraction methods to extract proteins from myofibrils of porcine myocardium. They reported that sonicated samples produced higher protein extraction rates without the need for high salt concentrations [15]. Tsermoula et al. (2018) compared alkali ( $\mathrm{pH} 11)$ and acid ( $\mathrm{pH}$ 2) solubilization followed by isoelectric precipitation to prepare protein-rich extracts from bovine and porcine hearts. Both myofibril extracts showed good heat-induced gelling properties, which allowed for inferring its potential application as functional ingredients for processed meat products [16].

The objective of the present study was gain insight into the knowledge of technofunctional properties of porcine heart soluble proteins, aiming at maximizing their applications in the most efficient way. Both the raw material and the extraction conditions determine the kind and the amount of proteins that can be solubilized, as well as their structure or unfolding degree. All these factors may have a great influence on the functionality of the protein extracts obtained. Thus, we followed the same approach previously used in the obtaining of protein concentrates from porcine spleens [11]. Response surface methodology (RSM) was used to foreknow the effects of the extraction conditions (at different $\mathrm{pH}$ and salt concentration of the buffer solution) on the physicochemical characteristics and technofunctional properties of the soluble protein extracts derived from pork heart. The functional properties, such as solubility, gelling, emulsifying, and foaming properties, were determined.

\section{Materials and Methods}

\subsection{Sample Collection and Preparation}

Fresh hearts from recently slaughtered white pigs (LargeWhite $\times$ Landrace $\times$ Pietrain $\times$ Duroc commercial crossbred; 6 months old and $100 \mathrm{~kg}$ weight) were supplied by a local industrial slaughterhouse (Norfrisa S.A., Riudellots de la Selva, Girona, Spain) and were transported at $5 \pm 1{ }^{\circ} \mathrm{C}$ to the laboratory. Firstly, the hearts were weighed and their $\mathrm{pHs}$ were measured in triplicate using a $\mathrm{pH}$ meter with a solid probe (LPG Crison 22, Barcelona, Spain). After being polished through removing fat and valves and blood vessels, hearts were divided into small pieces and kept refrigerated until they were analyzed or processed.

\subsection{Experimental Design}

The microbiological quality and physicochemical characterization of raw material were carried out on hearts collected in six different days but under the same conditions. Sample units for compositional analysis consisted of a mixture of pieces from at least four different hearts collected 
in the same day, which were minced in a blade grinder (Moulinex Moulinette MR, France) to obtain representative samples.

In a second stage, protein extraction processes were carried out. Aiming at performing a RSM analysis, a central composite design (CCD) for two process variables ( $\mathrm{pH}$ and ionic strength of the extraction buffer), five equidistant levels and five replicates at the central point ( $\mathrm{pH} 6.5$ and $2 \% \mathrm{NaCl}$ ) resulted in 13 experiments, which were performed randomly (Table 1). A blend of $4-5$ hearts were used in every experiment. The appropriate range of each operational factor was selected according to preliminary factorial experiments carried out in our laboratory: the $\mathrm{pH}$ conditions were 4.3, 5.0, 6.5, 8.0 , and 8.6 , and salt concentrations $0 \%, 0.58 \%, 2 \%, 3.42 \%$, and $4 \% \mathrm{NaCl}$, the same as for a previous study on porcine spleens [11].

Table 1. Experimental design for the optimization of the recovery technofunctional protein extracts from porcine hearts, according to the central composite design (CCD).

\begin{tabular}{cccccc}
\hline \multirow{2}{*}{ Run } & \multicolumn{2}{c}{ Coded Variables } & Order & \multicolumn{2}{c}{ Experimental Variables } \\
\cline { 5 - 6 } & & & & $\mathbf{p H}$ & $\mathbf{N a C l}$ (\%) \\
\hline 1 & -1 & -1 & 13 & 5 & 0.58 \\
2 & +1 & -1 & 5 & 8 & 0.58 \\
3 & -1 & +1 & 7 & 5 & 3.42 \\
4 & +1 & +1 & 12 & 8 & 3.42 \\
5 & $-\alpha$ & 0 & 6 & 4.3 & 2 \\
6 & $+\alpha$ & 0 & 1 & 8.6 & 2 \\
7 & 0 & $-\alpha$ & 3 & 6.5 & 0 \\
8 & 0 & $+\alpha$ & 10 & 6.5 & 4 \\
9 & 0 & 0 & 4 & 6.5 & 2 \\
10 & 0 & 0 & 9 & 6.5 & 2 \\
11 & 0 & 0 & 11 & 6.5 & 2 \\
12 & 0 & 0 & 8 & 6.5 & 2 \\
13 & 0 & 0 & 2 & 6.5 & 2 \\
\hline
\end{tabular}

Coded variables: 1 = high factor level, $-1=$ low factor level, $0=$ central point; negative and positive default $\alpha$-values indicate the low and high axial levels, respectively $(\alpha=1.414)$.

\subsection{Microbiological Analysis}

Heart samples were serially diluted in sterile tryptone water (tryptone $10 \mathrm{~g}$ (Oxoid, L42 Oxoid Ltd., Basingstoke, UK) and $\mathrm{NaCl} 5 \mathrm{~g} \mathrm{~L}^{-1}$ ), pour-plated in Petri plates with plate count agar (PCA, Oxoid CM361) as culture medium, and incubated aerobically at $30 \pm 1{ }^{\circ} \mathrm{C}$ for $72 \mathrm{~h}$ [17]. Total aerobic mesophilic bacteria were expressed as $\log _{10}$ colony-forming units per $\mathrm{g}\left(\log _{10} \mathrm{cfu} \mathrm{g}^{-1}\right)$. Microbiological analyses were performed the same day of sample collection and preparation.

\subsection{Protein Extraction}

Heart proteins extraction was carried out following the same method as described by Toldrà et al. (2019) [11] with slight modifications. Buffer extraction solutions were prepared with 1:15 M sodium dihydrogen phosphate and $0.1 \mathrm{M}$ citric acid ( $\mathrm{pH} 4.3$ ), 1:15 $\mathrm{M}$ potassium dihydrogen phosphate and 1:15 $\mathrm{M}$ sodium dihydrogen phosphate ( $\mathrm{pH} 5.0,6.5$, and 8.0), and $0.1 \mathrm{M} \mathrm{HCl}$ and $0.1 \mathrm{M}$ Tris ( $\mathrm{pH} 8.6$ ) in distilled water. $\mathrm{NaCl}$ was then added to the buffers according to the experimental design.

Five hundred grams of porcine heart, a mixture of pieces from at least four different organs, were introduced into a cutter vessel Sammic CKE-5 (Sammic S.L., Barcelona, Spain) and minced at $2100 \mathrm{rpm}$ for $45 \mathrm{~s}$. Subsequently, the ground sample was mixed, at $1800 \mathrm{rpm}$ for $2 \mathrm{~min}$, with $1000 \mathrm{~mL}$ of the corresponding buffer solution according to the CCD, and kept agitated at $300 \mathrm{rpm}$ for $30 \mathrm{~min}$ at room temperature. The suspensions were then centrifuged at $20,000 \times g$ for $15 \mathrm{~min}$ at $20^{\circ} \mathrm{C}$ in a Sorvall RC-SC plus centrifuge (Dupont Co, Newton, CT, USA), and the soluble fractions obtained by decanting were stored at $5{ }^{\circ} \mathrm{C}$ until analysis. 


\subsection{Physicochemical Characterization}

\subsubsection{Proximate Analysis}

Standard methods were used to analyze the proximate composition of porcine hearts and the soluble fractions of each extraction process. Each product was analyzed in triplicate. Moisture and ash contents were determined according to the Association of Official Analytical Chemists (AOAC) methods [18]. Protein content was estimated from the total Kjeldahl nitrogen $(T K N \times 6.25)$ [19] by using a digestion block (C. Gerhardt $\mathrm{GmbH} \& \mathrm{Co}$., Königswinter, Germany) and a distillation unit Büchi K-314 (Büchi Labortechnik AG, Flawil, Switzerland). Total collagen in heart samples was calculated from the hydroxyproline content $(\operatorname{Hyp} \times 8)$, which was determined through the NMKL-AOAC colorimetric method described by Kolar [20]. It consisted of protein hydrolysis with sulfuric acid, oxidation of hydroxyproline with chloramine-T, and formation of a red-purple complex with p-dimethylaminobenzaldehyde, which was measured at $560 \mathrm{~nm}$ by using a Cecil CE 1021 UV-Vis spectrophotometer (Cecil Instruments, Cambridge, UK). Total fat content was determined gravimetrically by Sohxlet extraction [21]. The fat was extracted for $5 \mathrm{~h}$ from the previously hydrolyzed and dried sample, using diethyl ether. The extraction solvent was removed through evaporation, and the residue was dried and subsequently weighed after cooling. Atomic emission spectrophotometry (SpectrAA Varian 50B; Agilent Technologies, Palo Alto, CA, USA) with a multielement lamp at a wavelength of $248.3 \mathrm{~nm}$ was used to analyze the iron content in aqueous solutions of previously ashed samples.

\subsubsection{SDS-Polyacrylamide Gel Electrophoresis (SDS-PAGE)}

SDS-PAGE was performed using acrylamide gels with stacking (T 3.94\%, C 2.66\%) and separating gel ( $\mathrm{T} 15 \%$, C 2.66\%) zones, which were prepared with acrylamide:bisacrylamide $40 \%$ (37.5:1) solution (Bio-Rad), according to the Laemmli method as described by Fort et al. [22], using a Mini-Protean ${ }^{\circledR} 3$ electrophoresis system (Bio-Rad Laboratories Inc., Hercules, CA, USA). Gels were run at $70 \mathrm{~V}$ for $30 \mathrm{~min}$ and then at a constant voltage of $120 \mathrm{~V}$ for $45-60 \mathrm{~min}$. The approximate molecular weights were estimated using molecular weights markers from 10 to $220 \mathrm{kDa}$ (BenchMark ${ }^{\mathrm{TM}}$ Protein Ladder, Invitrogen, Carlsbad, CA, USA). The gels were fixed with $2.5 \%$ gluteraldehyde solution, then stained with Coomassie Blue (0.1\% PhastGel Blue R solution in 30\% ethanol and $10 \%$ acetic acid), distained with $30 \%$ ethanol and 10\% acetic acid, and preserved in 10\% acetic acid and $10 \%$ glycerol.

Protein extracts were diluted at a ratio of 1:4 in pH 6.8, $10 \mathrm{mM}$ TrisHCl, $1 \mathrm{mM}$ EDTA, 1\% sodium dodecyl sulfate (SDS) and $1 \% \beta$-mercaptoethanol buffer, and subsequently heated at $100{ }^{\circ} \mathrm{C}$ for $5 \mathrm{~min}$ and centrifuged at $8000 \mathrm{rpm}$. Immediately before to the electrophoresis performance, these solutions were diluted to $50 \%$ with a buffer containing $1.25 \mathrm{~mL}$ Tris $\mathrm{HCl} 0.05 \mathrm{M} \mathrm{pH}$ 8.8, 1\% SDS, $2 \mathrm{~mL}$ glycerol, and $1.75 \mathrm{~mL}$ alcoholic solution of bromophenol blue $(0.01 \%)$ as tracking dye.

\subsection{Technofunctional Properties}

\subsubsection{Protein Solubility}

Protein solubility was calculated from the protein content and the corresponding yield of soluble fraction obtained after protein extraction procedure as explained in "Protein Extraction" (Section 2.4), relative to the total protein content of heart.

\subsubsection{Foaming Properties}

The foaming properties were determined as described in Davila et al. [23]. Three aliquots of $200 \mathrm{~mL}$ of protein solutions $\left(5 \mathrm{~g} \mathrm{~L}^{-1}\right)$ of every fraction were prepared in distilled water, and then transferred to $1000 \mathrm{~mL}$ volumetric flasks. Solutions were whipped in a Braun Multimix M700 mixer (Braun Española S.A., Barcelona, Spain) with two whisks $(\varnothing=5 \mathrm{~cm})$ at $1000 \mathrm{rpm}$ for $10 \mathrm{~min}$. The flasks were placed on a rotational plate during mixing to form homogeneous foams. Afterward, the foaming 
capacity (FC) was determined as the volume $(\mathrm{mL})$ of foam after 2 min at rest. Foam stability was determined using a gravimetric method as follows: measured quantities of foam were carefully placed in three dry stainless steel sieves to let the released liquid drain, and the remaining foam was weighted every $10 \mathrm{~min}$ for a period of $60 \mathrm{~min}$. The percentage of remaining foam versus time was plotted, and relative foam stability (RFS), defined as the time ( $\mathrm{min}$ ) needed for the disappearance of $50 \%$ of the initial foam, was calculated by fitting data to an exponential decay function $y=y_{0}+a \times 10^{(-b x)}$.

\subsubsection{Emulsifying Properties}

The turbidimetric method reported by Pearce and Kinsella [24] with slight modifications [25] was used to determine the emulsifying properties. Solutions of protein extracts in distilled water were prepared at $5 \mathrm{~g} \mathrm{~L}^{-1}$ of protein. One hundred fifty milliliters of each solution was homogenized along with $50 \mathrm{~mL}$ of commercial corn oil using a hand-operated laboratory piston-type homogenizer (MFC MicrofluidizerTM Series 5000, Microfluidics Corporation, Newton, MA, USA) at 12 MPa and $40 \mathrm{~L} \mathrm{~h}^{-1}$ output flow, with recirculation for $90 \mathrm{~s}$. Triplicate preparations were carried out for each sample. The emulsions were diluted 2500 -fold with $0.1 \%$ sodium dodecyl sulfate (SDS), immediately after homogenization $(t=0)$ and after 10 min of emulsion rest $(t=10)$. The absorbance of the diluted emulsions was then determined at $500 \mathrm{~nm}$ in a Cecil CE 7400 spectrophotometer (Cecil Instruments Ltd., Cambridge, UK). Each determination was performed in duplicate. Results were reported as emulsifying activity index (EAI) and emulsion stability index (ESI), which were calculated as follows: EAI $\left(\mathrm{m}^{2} \mathrm{~g}^{-1}\right.$ protein $)=2 \cdot \mathrm{T} / \phi \cdot \mathrm{C}$; where $\mathrm{T}$ is turbidity, $\phi$ is the volume fraction of the dispersed phase, and $C$ is the weight of protein per unit volume of aqueous phase before the emulsion is formed; $\mathrm{ESI}(\min )=\mathrm{T} \cdot(\Delta \mathrm{t} / \Delta \mathrm{T})$; where $\Delta \mathrm{T}$ is the change in turbidity $(\mathrm{T})$ occurring during the interval $\Delta \mathrm{t}$ (between $\mathrm{t}=0$ and $\mathrm{t}=10 \mathrm{~min})$.

\subsubsection{Heat-Induced Gelation}

The heat-induced gelation capacity of the soluble fractions was tested. Five aliquots of $20 \mathrm{~mL}$ of every sample were poured into twist-off glass containers (50 $\mathrm{mm}$ in diameter and $20 \mathrm{~mm}$ in depth), hermetically closed, and heated for $40 \mathrm{~min}$ in a water bath at $80 \pm 1{ }^{\circ} \mathrm{C}$. After that, samples were immediately cooled at room temperature. A uniaxial compression test with a TA-XT2 texture analyzer (Stable Micro Systems Ltd., Surrey, UK) was undertaken on the samples in the same receptacle where the gelation was produced. A cylindrical aluminum plunger of $25 \mathrm{~mm}$ diameter was used to compress samples until $50 \%$ deformation at a rate of $1 \mathrm{~mm} \mathrm{~s}^{-1}$. The strain/distance curve was recorded and the total work involved in performing the test was considered as a measure of gel firmness $(\mathrm{N} \mathrm{mm})$. Mean values $(n=5)$ were used for sample comparison.

\subsection{Statistical Analysis}

The SPSS software package version 23.0 (2015) for Windows (IBM Corporation, Armonk, NY, USA) was used for statistical analysis. The experimental data of the protein extracts were fitted to a second-degree polynomial regression model, which included the coefficients of linear, quadratic, and the two-factor interaction effects. Parameters of the second-order polynomial model were estimated using the linear regression procedure with the backward method (inclusion and exclusion criteria at $p<0.05$ and $p>0.1$, respectively). Analysis of variance (ANOVA) was performed for the models calculated from the linear regression and the criteria used to evaluate the models were the $\mathrm{R}^{2}$ adj value, and significance of the model and the estimated coefficients. Significance was attained for $p<0.05$. The 3D response graphs of predicted values through the RSM models were plotted using SigmaPlot for Windows v. 11 (2008) (Systat Software Inc., San Jose, CA, USA). 


\section{Results and Discussion}

\subsection{Physicochemical and Microbiological Characterization of Porcine Hearts}

Proximate composition, collagen and iron content, weight, $\mathrm{pH}$, color, and microbiological counts from porcine hearts are shown in Table 2. The average weight of the hearts was $407.67 \pm 36.14 \mathrm{~g}$ and the $\mathrm{pH} 5.89 \pm 0.10$, which is in the normal $\mathrm{pH}$ range of pork meat (5.6-6.2). Overall proximate composition did not differ much from that reported by Tsermoula et al. [16], except for the slightly higher humidity in our samples and the consequent somewhat lower values of the other components, but leading to similar moisture:protein ratios [16]. Moisture in the heart samples analyzed was also 3.5\% higher than that reported by Seong et al. [26], who also found fat contents that doubled our values. Such variability could be explained not only by the different crossbred used in both studies but also by the higher life weights of the pigs, which in the referred work were reported to be about $130-140 \mathrm{~kg}$. The total mesophilic aerobic bacterial counts were in the interval between 3 and 4 log units, in agreement with the values reported elsewhere [27], and within the range of acceptability of the hygienic processing criteria for meat products (Commission Regulation (EC) No. 2073/2005) [28].

Table 2. Physicochemical characteristics and microbiological quality of raw porcine hearts (means \pm SD, $n=6)$.

\begin{tabular}{lc}
\hline Weight $(\mathrm{g})$ & $407.67 \pm 36.14$ \\
$\mathrm{pH}$ & $5.89 \pm 0.10$ \\
Moisture $(\%)$ & $79.31 \pm 0.34$ \\
Protein $(\%)$ & $16.70 \pm 0.18$ \\
$\quad$ Collagen $(\%)$ & $1.13 \pm 0.30$ \\
Fat $(\%)$ & $2.46 \pm 0.54$ \\
Ashes $(\%)$ & $1.04 \pm 0.07$ \\
Iron $(\mathrm{ppm})$ & $60.33 \pm 20.19$ \\
Color properties & \\
$\quad$ Chroma & $19.79 \pm 0.59$ \\
Hue $\left({ }^{\circ}\right)$ & $25.60 \pm 1.39$ \\
$\quad$ Lightness $\left(\mathrm{L}^{*}\right)$ & $32.55 \pm 1.16$ \\
Bacterial counts $\left(\log \mathrm{cfu} \mathrm{g}^{-1}\right)$ & $3.49 \pm 0.46$ \\
\hline
\end{tabular}

\subsection{Extractability and Compositional Characteristics of Heart Protein Fractions}

Table 3 shows the yield of every extraction process and the proximate composition of the soluble extracts as a function of $\mathrm{pH}$ and salt concentration of the extraction buffer. A significant increase in viscosity was observed in all solutions after refrigeration at $5{ }^{\circ} \mathrm{C}$, in some cases (all extracts at $\mathrm{pH} \geq 6.5$ ) becoming very dense solutions with lumpy gelled appearance.

Concerning the proximate composition of the protein extracts, average contents of $94.9 \pm 1.1 \%$ moisture, $2.91 \pm 0.5 \%$ protein, and $1.8 \pm 0.75 \%$ ashes, were obtained. The $\mathrm{NaCl}$ added to the extraction buffer influenced the moisture content of the soluble extracts. As expected, low $\mathrm{NaCl}$ entailed a lower ash content and consequently higher relative moisture in the liquid extracts. At any $\mathrm{pH}$, the protein content of the extracts was higher at increasing ionic strength. Although there was not as much clear effect of the $\mathrm{pH}$, for the same $\mathrm{NaCl}$ content the highest protein percentage was always found in the extracts obtained at higher $\mathrm{pH}$ values.

As can be observed, the average yield of soluble fraction for all extractions was $68.03 \pm 1.74$; the most distant from the mean value were the extracts obtained at $\mathrm{pH} 5$ and $3.42 \% \mathrm{NaCl}$, which showed the minimum yield (59.5\%), and at $\mathrm{pH} 8.6$ and $2 \% \mathrm{NaCl}$, which reached the maximum (72.82\%). The highest values corresponded to the $\mathrm{pH}$ axial points, $\mathrm{pH} 8.6$ and 4.3, both containing the salt content corresponding to the central point $(2 \% \mathrm{NaCl})$. Overall, all processes at $\mathrm{pH} 6.5$ resulted in a yield close to the mean value, regardless of their ionic strength. Nevertheless, the same behavior was found when combining acid $\mathrm{pH}$ with low salt or alkaline $\mathrm{pH}$ with a considerable amount of $\mathrm{NaCl}$. It is worth noting 
that the extract obtained by using a buffer at $\mathrm{pH} 8.6$ and $2 \% \mathrm{NaCl}$ was the one that showed both the best yield and the highest protein content.

Table 3. Yield and proximate composition of soluble protein fractions from porcine heart as influenced by $\mathrm{pH}$ and $\mathrm{NaCl}$ content $(\%)$ of the extraction buffer.

\begin{tabular}{cccccc}
\hline \multirow{2}{*}{$\mathbf{p H}$} & $\mathbf{N a C l}$ & Yield (\%) & \multicolumn{3}{c}{ Proximate Composition (\%) } \\
\cline { 4 - 6 } & & & Moisture & Protein & Ash \\
\hline $\mathbf{5}$ & 0.58 & 67.2 & 96.63 & 2.33 & 0.89 \\
$\mathbf{8}$ & 0.58 & 63.2 & 95.57 & 2.85 & 1.11 \\
$\mathbf{5}$ & 3.42 & 59.5 & 93.78 & 3.03 & 2.74 \\
$\mathbf{8}$ & 3.42 & 68.6 & 94.21 & 3.35 & 2.00 \\
$\mathbf{4 . 3}$ & 2 & 71.3 & 95.63 & 1.79 & 2.01 \\
$\mathbf{8 . 6}$ & 2 & 72.8 & 94.61 & 3.59 & 1.62 \\
$\mathbf{6 . 5}$ & 0 & 68.6 & 96.82 & 2.24 & 0.37 \\
$\mathbf{6 . 5}$ & 4 & 67.7 & 92.84 & 3.35 & 3.30 \\
$\mathbf{6 . 5}$ & 2 & $68.0 \pm 1.7$ & $94.64 \pm 0.39$ & $1.88 \pm 0.20$ & $3.05 \pm 0.01$ \\
\hline
\end{tabular}

Central point ( $\mathrm{pH} 6.5$ and $2 \% \mathrm{NaCl}) ;$ mean $\pm \mathrm{SD}(n=5)$.

Soluble protein recovery was calculated from the protein content of the extracts referred to the corresponding yield of the extraction process and it was reported as protein solubility, that is, percentage of protein in the solutions with respect to the total protein content of porcine heart (Table 4). Solubility ranged from $22.4 \%$ (at $\mathrm{pH} 4.3$ and $2 \% \mathrm{NaCl}$ ) to $44.3 \%$ (at $\mathrm{pH} 8.6$ and $2 \% \mathrm{NaCl}$ ), confirming the influence of $\mathrm{pH}$ in this property. In our heart extracts, the protein contents were somewhat higher while the solubility was slightly lower, as compared to protein extracts from porcine spleen obtained in a previous study, due to the different ratio of solvent to material used in the extraction processes, 10:1 for the spleen proteins and 2:1 for the heart proteins, which result in a higher protein content solution but with a lower solubilization yield [11]. Protein yields around $50 \%(w / w)$ were obtained in several studies on the extraction of water and salt soluble proteins from bovine coproducts [14,29]. According to Selmane et al., yields of protein recovery from pork and beef lungs were between 48 and $55 \%(w / w)$ [30]. Moreover, Tsermoula et al. reported 51.53-55.74\% recovery of the total protein from bovine and porcine hearts through alkali and acid solubilization [16].

Table 4. Technofunctional properties of soluble protein fractions from porcine heart as influenced by $\mathrm{pH}$ and $\mathrm{NaCl}$ content (\%) of the extraction buffer.

\begin{tabular}{cccccccc}
\hline \multirow{2}{*}{$\mathbf{p H}$} & \multirow{2}{*}{ NaCl } & \multirow{2}{*}{ Solubility (\%) } & \multicolumn{2}{c}{ Foaming } & \multicolumn{2}{c}{ Emulsifying } & \multicolumn{2}{c}{ Gelling } \\
\cline { 3 - 7 } & & FC & RFS & EAI & ESI & GS \\
\hline 5 & 0.58 & 26.9 & 596.5 & 8.53 & 236.44 & 20.13 & 1.31 \\
8 & 0.58 & 29.9 & 375.9 & 12.37 & 297.32 & 170.62 & 2.18 \\
5 & 3.42 & 31.5 & 572.0 & 12.89 & 278.89 & 41.10 & 1.19 \\
8 & 3.42 & 38.9 & 343.2 & 8.03 & 150.39 & 22.47 & 11.47 \\
4.3 & 2 & 22.4 & 738.1 & 22.04 & 259.09 & 25.65 & 0.82 \\
8.6 & 2 & 44.3 & 283.3 & 16.17 & 251.79 & 19.94 & 2.42 \\
6.5 & 0 & 26.3 & 365.0 & 5.55 & 354.74 & 35.19 & 2.15 \\
6.5 & 4 & 39.2 & 324.1 & 11.64 & 206.35 & 26.15 & 18.77 \\
6.5 & 2 & $35.8 \pm 1.1$ & $326.8 \pm 41.6$ & $11.15 \pm 1.78$ & $308.00 \pm 39.01$ & $25.32 \pm 6.50$ & $5.38 \pm 0.89$ \\
\hline
\end{tabular}

FC: foaming capacity $(\mathrm{mL})$. RFS: relative foam stability $(\mathrm{min})$. EAI: emulsifying activity index $\left(\mathrm{m}^{2} \mathrm{~g}^{-1}\right)$. ESI: emulsifying stability index (min). GS: gel firmness $(\mathrm{N} \mathrm{mm})$. Central point $(\mathrm{pH} 6.5$ and $2 \% \mathrm{NaCl})$; mean $\pm \mathrm{SD}$ $(n=5)$.

The quadratic model for solubility was found to be significant $(p=0.000)$ and revealed an adjusted coefficient of determination ( $R^{2}$ adj) of 0.978 (Table 5 ), indicating that close to $98 \%$ of experimental 
data variation is explained by the estimated equation. The proposed quadratic model includes $\mathrm{pH}$ and $\mathrm{pH}^{2}, \mathrm{NaCl}$ concentration, and three $\mathrm{pH}-\mathrm{NaCl}$ interactions. It is widely understood that the solubility of a protein is highly dependent on $\mathrm{pH}$ and salt concentration. As shown in the response surface (Figure $3 \mathrm{a}$ ), higher solubility values correspond to the $\mathrm{pH}$ range from 6.5 to 8.5 , and solubility improves with salt addition from 1.5 to $3 \% \mathrm{NaCl}$, due to an enhancement of myofibrillar proteins solubilization by salt. These results agree with studies on porcine cardiac proteins [15] or proteins extracted from other sources, i.e., porcine spleen [11] or mechanically separated turkey meat [31]. Additionally, ultrasonic treatments were claimed as useful to increase the effective extraction of protein from normal residual meat byproducts such as porcine myocardium without the need for high salt concentrations, as required in conventional extraction methods [15].

Table 5. Polynomial models for the response surface methodology (RSM) optimization of functionality of protein extracts from porcine heart as a function of $\mathrm{pH}$ and salt concentration of the extraction buffer.

\begin{tabular}{ccccccc}
\hline & Protein Solubility (\%) & \multicolumn{2}{c}{ Foaming } & \multicolumn{2}{c}{ Emulsifying } & Gelling \\
\cline { 3 - 7 } & & FC & RFS & EAI & ESI & GS \\
\hline Coefficients & & & & & & \\
Constant & 14.762 & 2732.309 & 64.900 & -385.954 & -110.123 & 1.629 \\
$\mathrm{pH}$ & 6.090 & -647.477 & -18.880 & 201.037 & $\mathrm{~ns}$ & $\mathrm{~ns}$ \\
$\mathrm{NaCl}$ & -16.740 & $\mathrm{~ns}$ & 4.396 & $\mathrm{~ns}$ & 55.987 & $\mathrm{~ns}$ \\
$\mathrm{pH} \mathrm{HaCl}^{*} \mathrm{na}$ & $\mathrm{ns}$ & $\mathrm{ns}$ & $\mathrm{ns}$ & $\mathrm{ns}$ & $\mathrm{ns}$ \\
$\mathrm{pH}^{2}$ & -0.669 & 43.023 & 1.502 & -13.923 & 3.971 & $\mathrm{~ns}$ \\
$\mathrm{NaCl}^{2}$ & $\mathrm{~ns}$ & $\mathrm{~ns}$ & $\mathrm{~ns}$ & 28.200 & $\mathrm{~ns}$ & -11.310 \\
$\mathrm{pH}^{2 *} \mathrm{NaCl}^{*}$ & 0.550 & $\mathrm{~ns}$ & $\mathrm{~ns}$ & $\mathrm{~ns}$ & -1.576 & $\mathrm{~ns}$ \\
$\mathrm{pH}^{*} \mathrm{NaCl}^{2}$ & 1.408 & $\mathrm{~ns}$ & $\mathrm{~ns}$ & -5.456 & $\mathrm{~ns}$ & 3.544 \\
$\mathrm{pH}^{2 *} \mathrm{NaCl} \mathrm{N}^{2}$ & -0.236 & $\mathrm{~ns}$ & -0.021 & $\mathrm{~ns}$ & $\mathrm{~ns}$ & -0.253 \\
\hline $\mathrm{Adjusted}^{2}$ & 0.978 & 0.901 & 0.614 & 0.655 & 0.490 & 0.946 \\
Significance & 0.000 & 0.000 & 0.017 & 0.011 & 0.028 & 0.000 \\
\hline
\end{tabular}

FC: foaming capacity (mL); RFS: relative foam stability (min); EAI: emulsifying activity index $\left(\mathrm{m}^{2} \mathrm{~g}^{-1}\right)$; ESI: emulsifying stability index ( $\mathrm{min})$; GS: gel firmness $(\mathrm{N} \mathrm{mm}$ ); ns: not significant (variable not included in the model).

\subsection{SDS-PAGE Profiles}

SDS-PAGE electrophoretograms of soluble protein fractions from porcine hearts are shown in Figure 1. All samples showed broadly similar electrophoretic profiles with bands corresponding to the MW of the major sarcoplasmic and myofibrillar myocardial proteins, as well as blood proteins.

Soluble protein fractions are composed mainly of myofibrillar proteins, actin, and myosin [14,32]. All samples exhibited bands corresponding to heavy $(\mathrm{H})$ and light $(\mathrm{L})$ myosin chains (with a MW of 200-220 and 15-25 kDa, respectively) and bands around 40-50 kDa that could correspond to the globular monomeric form of actin (G-actin) (MW of $42 \mathrm{kDa}$ ) [15,33]. Bands in the range between 30 and $40 \mathrm{kDa}$ may be assigned to the regulatory proteins associated with actin, troponin complex, and tropomyosin. Sarcoplasmic proteins are water-soluble globular proteins of relatively low MW (15-20 kDa), consisting mainly of enzymes and hem pigments [29]. Other bands in the range from 20 to $70 \mathrm{kDa}$ can be observed in all samples, probably corresponding to blood proteins, albumin (MW 68-70 kDa), which is the most abundant globular protein in plasma; globulins, a heterogeneous group of globular proteins that include a variety of enzymes, carrier, and antigenic proteins with MW ranging from few to hundreds $\mathrm{kDa}$; and proteins associated to red cell membranes ( $\mathrm{MW} \sim 30-240 \mathrm{kDa}$ ) [34,35].

From the main differences among samples, presumably attributable to the $\mathrm{pH}$ and ionic strength of the extraction buffer, we can make the following remarks:

Focusing on myosin, the solubility is favored by extraction conditions combining high $\mathrm{pH}$, far from the isoelectric point, together with high ionic strength. This is likely due to alkaline $\mathrm{pH}$ loosening the tissues and facilitating structural changes [15]. Samples at pH 8.6 (lane 7) and $\mathrm{pH} 8$ (lane 5) showed 
the most intense bands of heavy myosin $(220 \mathrm{kDa})$ along with the presence of a band that matches the MW of light myosin $(20 \mathrm{kDa})$. At pH 4.3 and 5 the light chain is not observed and the intensity of the myosin $\mathrm{H}$ band is weaker. Increasing the ionic strength of the buffer by the addition of $\mathrm{NaCl}$ aids myosin extraction, as confirmed by the fading of the myosin $\mathrm{H}$ band and the absence of the myosin $\mathrm{L}$ band in samples with low salt content $(0.58 \% \mathrm{NaCl})$, despite being at $\mathrm{pH} 8$ (lane 3 ). This effect is also noticeable even when comparing samples at pH 6.5 (lanes 8,9 , and 10), since a slight increase in myosin recovery can be observed as salt concentration increases, in agreement with the protein solubility results. On the other hand, the bands corresponding to the molecular weight of G-actin also show greater intensity in soluble extracts at $\mathrm{pH} \geq 5$ and seems to be less influenced by $\mathrm{NaCl}$ contents.

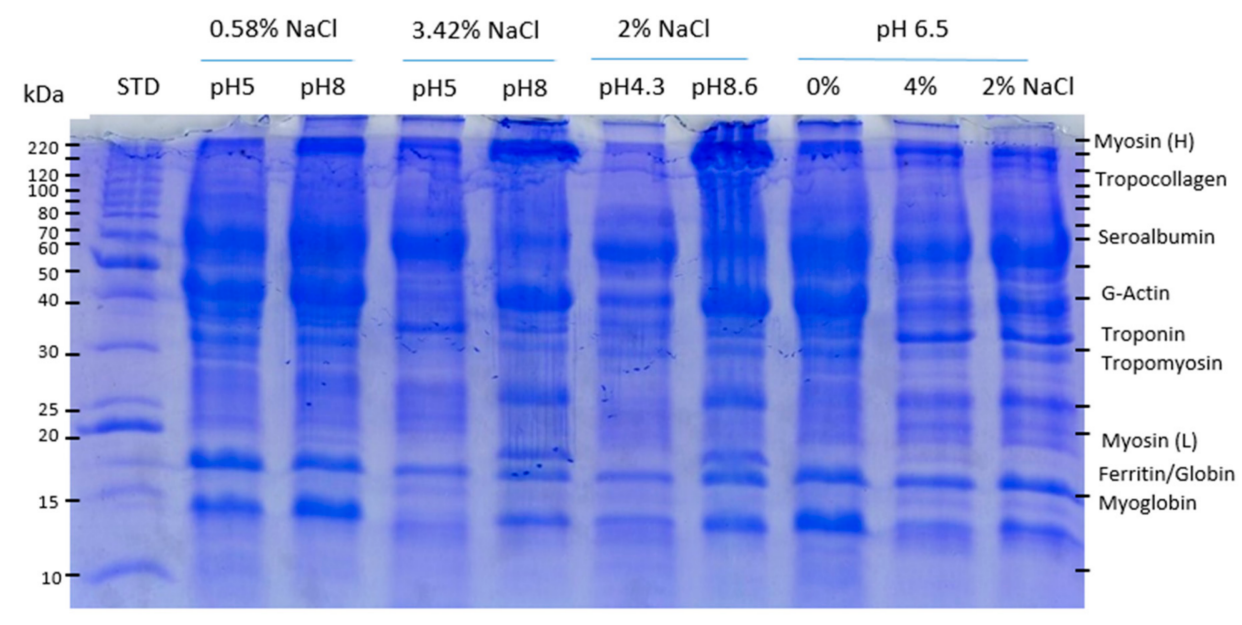

Figure 1. SDS-PAGE (12.5\% PA) patterns of soluble proteins extracted from porcine heart as a function of $\mathrm{pH}$ and salt concentration of the extraction buffer. STD: molecular weight standard from 10 to $200 \mathrm{kDa}$.

One band in the range 25-30 kDa can be observed only in some extracts, those corresponding to $\mathrm{pH} \geq 6.5$ and salt content $\geq 2 \%$. The band could putatively be assigned to low MW salt soluble globulins or several sarcoplasmic enzymes (myokinase, triosephosphate isomerase, phosphoglycerate mutase) [36].

Moreover, in most protein extracts there were two bands in the range of 15-20 kDa MW that follow the same pattern of intensity among the different samples. Looking at their MW, the band of lower MW may correspond to the hemoproteins, myoglobin, and the globin monomer of hemoglobin (16-18 kDa MW approximately), and the other band, with a slightly higher MW (19-21 kDa) to ferritin subunits [37]. The effect of ionic strength on these proteins can be easily observed by comparing the three samples at pH 6.5 (lanes 8-10), the two samples at pH 8 (lanes 3 and 5) or at pH 5 (lanes 2 and 4). The intensities of the bands are always greater in samples with low salt content $(0-0.58 \%)$ for all $\mathrm{pHs}$. The effect of $\mathrm{pH}$ is evidenced from the comparison of $2 \% \mathrm{NaCl}$ samples at $\mathrm{pH} 4.3,8.6$, and 6.5 (lanes 6, 7 , and 10, respectively). The bands become paler as $\mathrm{pH}$ decreases; the highest intensity corresponding to samples at alkaline $\mathrm{pH}$.

Although SDS-PAGE, as carried out in this study, cannot be considered as a quantitative method, it has been shown that differences in polypeptide profiles may be related to the functional properties of protein samples [38].

\subsection{Effects of the Extraction Conditions on the Functional Properties of Soluble Protein Extracts}

The technofunctionality of protein extracts obtained at different extraction conditions are shown in Table 4. Significant second-order polynomial models were obtained for all the response variables $(p<0.05)$ (Table 5). The 3D response surface graphs and contour plots can be found in Figure 3. 


\subsubsection{Foaming Properties}

Proteins are known to enhance and to stabilize foams by adsorbing at the air-liquid interface after undergoing unfolding and molecular rearrangement. Looking at the experimental results on foamability (Table 4), highest foaming capacity (FC) and stability (RFS) corresponded to the solutions extracted with acid buffers. FC values ranged from 283 to $738 \mathrm{~mL}$ of foam. It showed low values for solutions at $\mathrm{pH} \geq 6.5$ and reached higher values at $\mathrm{pH} 5(572 \mathrm{~mL})$ and at $\mathrm{pH} 4.3(738 \mathrm{~mL})$. At $\mathrm{pH}$ 6.5-8.3, a drop of up to about half the volume of foam as compared to the acid extracts was observed. This behavior is in agreement with the one described for other proteins, e.g., globulins from porcine plasma [23]. Concerning the foam stability (Figure 2, RFS values Table 4), the more unstable foam corresponded to the extract recovered at $\mathrm{pH} 6.5$ without added $\mathrm{NaCl}$, and the one showing better stability was again the one produced with the solution of the acid extract (pH 4.3). At pH 5 and 6.5 and using a buffer with increased ionic strength $(2-4 \% \mathrm{NaCl})$ improved the foam stability of the protein extracts. RFS was also good for solutions at $\mathrm{pH} 8.6$, but this feature is of little relevance due to the fact that it was the extract with the lowest foaming capacity $(283.3 \mathrm{~mL})$.

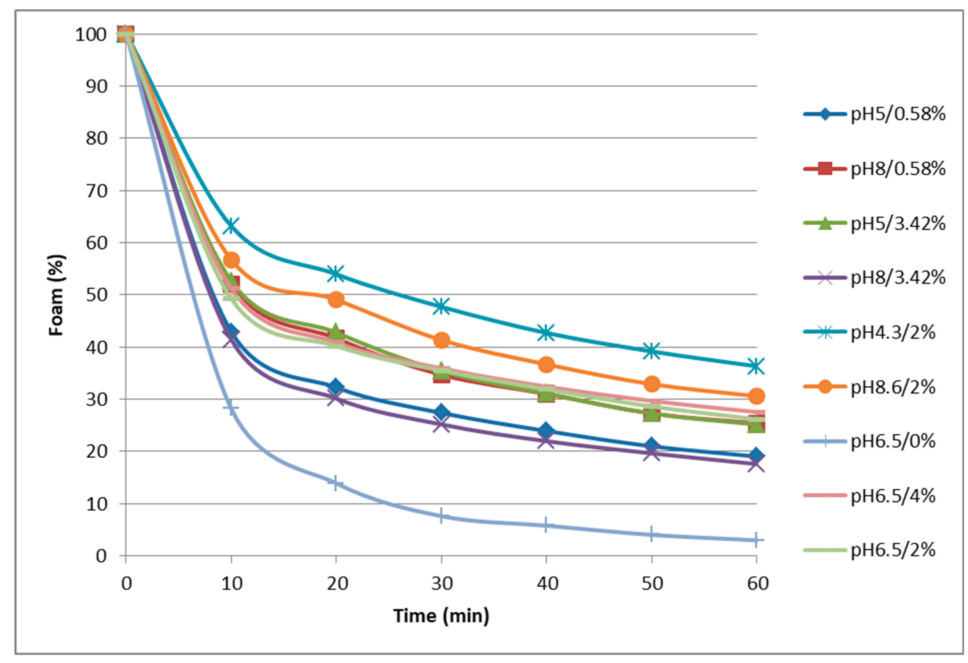

Figure 2. Vanishing kinetics of foam from porcine heart protein extracts $\left(5 \mathrm{~g} \mathrm{~L}^{-1}\right)$, obtained with extraction buffers at different $\mathrm{pH}$ and $\mathrm{NaCl}$ contents. Points refer to the relative percentage of the initial foam remaining at $10 \mathrm{~min}$ intervals.

Since the foaming properties of proteins are related to their hydrophobicity and their charge [39], our results could be explained by increased protein surface hydrophobicity at acid $\mathrm{pH}$. The unfolding of protein molecules exposes hydrophobic groups, resulting in increased interaction at the air-water interface. According to Yang et al., the hydrophobicity of myofibrillar proteins decrease as $\mathrm{pH}$ increases from 5.0 to 8.0 [40].

Table 5 shows the models that better fit to our experimental data on FC and RFS. The response surfaces of both variables are shown in Figure $3 c$,d, respectively. Regarding to the second-order polynomial functions obtained, the FC response can be explained by the $\mathrm{pH}$ of the extraction buffer itself and shows a good fit to the experimental data $\left(R^{2}=0.901\right)$. Conversely, a more complex model that includes $\mathrm{NaCl}$ concentration and $\mathrm{pH}-\mathrm{NaCl}$ interaction was obtained for the RFS variable, although it shows a worse fit to the experimental data $\left(R^{2}=0.614\right)$. As can be seen in Figure $3 c$, foaming ability reaches a maximum at acidic $\mathrm{pH}$ values and worsens with increasing $\mathrm{pH}$, this behavior being irrespective of the $\mathrm{NaCl}$ concentration. The model proposes that the $\mathrm{FC}$ of $5 \mathrm{~g} \mathrm{~L}^{-1}$ solutions $(200 \mathrm{~mL})$ of the water-soluble heart proteins after the whipping process would be good at $\mathrm{pH}$ lower than 5.5, with specific foam volumes of 500-750 mL. Surprisingly, the behavior of the FC variable for porcine heart extracts showed to be opposite to the extracts coming from porcine spleen, as reported in 
Toldrà et al. [11], thus confirming the influence of both the raw material and the extraction process in the technofunctionality of the soluble extracts obtained from different organs [30,41]. Only the heart extracts obtained at acidic $\mathrm{pH}$ showed foaming capacity comparable to the extracts from spleen proteins, which had shown to be good at any $\mathrm{pH}$. This behavior can also be related to the solvent:material proportions used to obtain heart extracts; with a ratio of 2:1, a solubilization yield lower than that obtained with the 10:1 ratio used for extractions of soluble spleen proteins. It is possible that the availability of solvent acted as a limiting factor and the proteins with the best surface properties remained in the insoluble residue, even at the most favorable $\mathrm{pH}$ and ionic strength conditions for their extraction.
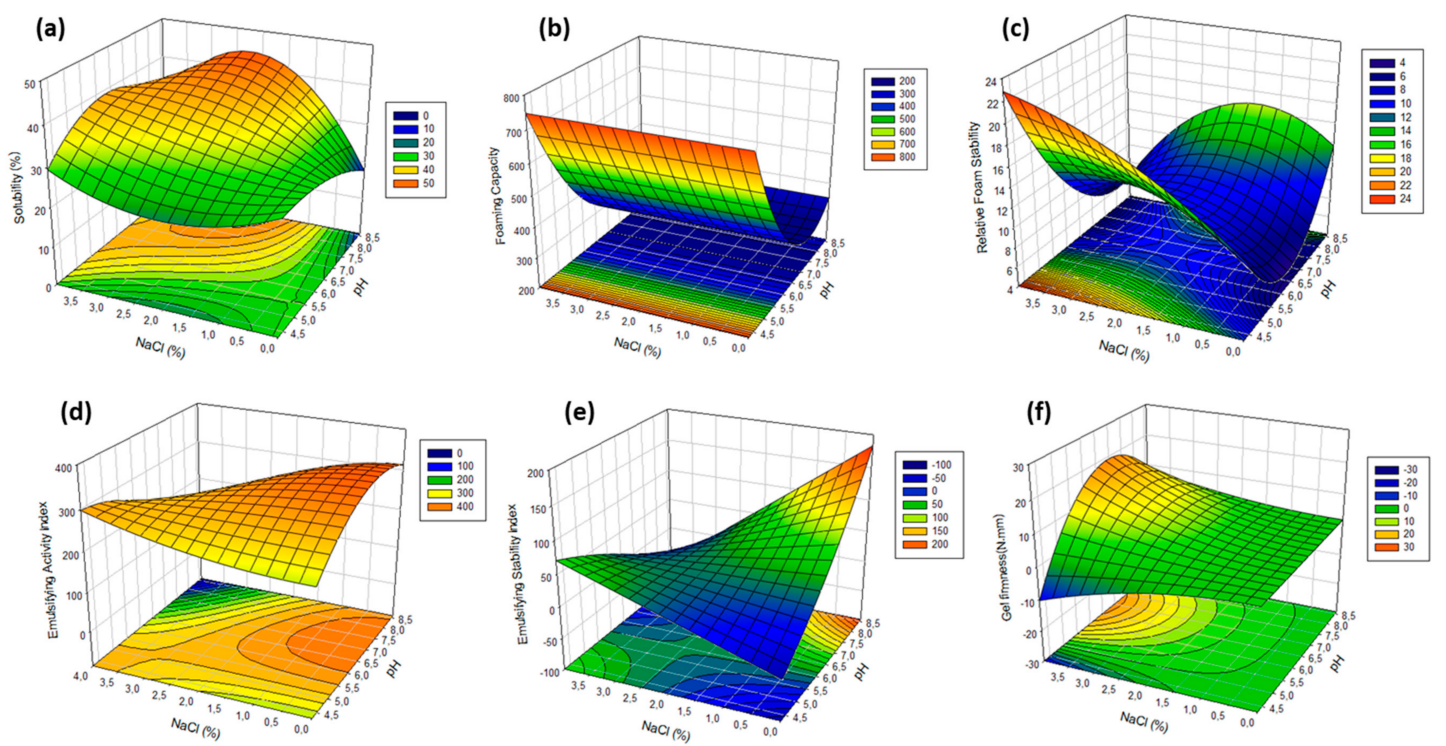

Figure 3. Response surface graphs and contour plot of the protein extracts from porcine heart as a function of $\mathrm{pH}$ and salt concentration of the extraction buffer. (a) Protein solubility (\%) and surface properties (5 $\mathrm{g} \mathrm{L}^{-1}$ protein); (b) foaming capacity $(\mathrm{mL})$; (c) relative foam stability (min); (d) emulsifying activity index $\left(\mathrm{m}^{2} \mathrm{~g}^{-1}\right)$; (e) emulsion stability index ( $\left.\mathrm{min}\right)$; and (f) gel firmness after heating $\left(80{ }^{\circ} \mathrm{C}\right.$ for $40 \mathrm{~min})(\mathrm{N} \mathrm{mm})$.

According to the response surface for the variable RFS (Figure 3d), the foam stability can also be considered acceptable at acid conditions and improves with increasing $\mathrm{NaCl}$ concentration. The foams show to reach maximum stability at low $\mathrm{pH}$ values and high ionic strength, with a linear increase from 0 to $4 \% \mathrm{NaCl}$ when using an extraction buffer at $\mathrm{pH} 4.5$. The predicted minimum foam stability corresponds to $\mathrm{pH}$ near the isoelectric point ( $\mathrm{pI}$ ) of myofibrillar proteins ( $\mathrm{pH}$ 5-5.5). This fact could be a consequence of the protein precipitation, so that there would not be enough protein able to adsorb at the surfaces. Far from this $p I$, proteins with flexible structure form denser and thicker adsorption layers, thus ensuring better stabilization. Added $\mathrm{NaCl}$ at acid $\mathrm{pH}$ increases further the adsorption and the repulsion between the surfaces (probably by steric and/or osmotic mechanism).

From our results, the best extraction conditions to obtain a soluble protein fraction from porcine hearts with good foaming properties would correspond to acid $\mathrm{pH}$ and high salt content.

\subsubsection{Emulsifying Properties}

The emulsification properties of acid and alkaline extracted proteins were evaluated by their ability to form and stabilize oil-in-water emulsions. EAI indicates the ability of protein to adsorb at the interface during the formation of emulsion, avoiding flocculation and coalescence of the small fat droplets. ESI estimates the decreasing rate of the emulsion turbidity due to fat droplet coalescence and 
creaming. Therefore, EAI and ESI increase when proteins favor emulsion formation and stabilization, respectively [30].

Experimental results concerning emulsifying properties are shown in Table 4 . The mean EAI value for all the protein extracts was $260.3 \pm 59.7 \mathrm{~m}^{2} \mathrm{~g}^{-1}$, ranging from $150.4(\mathrm{pH} 8$ and $3.42 \% \mathrm{NaCl})$ to 354.7 ( $\mathrm{pH} 6.5$ without added $\mathrm{NaCl}$ ). Overall, solutions at $\mathrm{pH}>6.5$ with low $\mathrm{NaCl}$ contents were the ones leading to higher EAI. Steen et al. also found that an increase in salt concentration decreased the emulsifying properties of water and salt soluble proteins from pork liver [29]. Nevertheless, in our results the low emulsifying activity of acid solutions ( $\mathrm{pH} 5)$ seemed to be somewhat compensated by increasing $\mathrm{NaCl}$. In fact, the impact of salt on the emulsifying properties of proteins, both of animal and vegetable origin, which can be found in the literature leads to contradictory results and diverse mechanisms are proposed to support each finding [29]. Looking at ESI, significantly more stable emulsions were obtained at $\mathrm{pH} 8$ and $0.58 \% \mathrm{NaCl}(170.62 \mathrm{~min})$ as compared to the rest of extracts, which on the whole showed an average ESI value of about $26.43 \pm 7.17 \mathrm{~min}$. Dàvila et al. [23] also reported ESI values for porcine plasma globulins and albumin from four- to five-fold higher at $\mathrm{pH} 7.5$ than at lower $\mathrm{pH}$ ( $\mathrm{pH} 6.5$ and 4.5), which were attributed to the effect of protein aggregation phenomena induced by acidification. However, none of the other alkaline extracts with higher ionic strength allowed for obtaining such stable emulsions.

Regardless of the fractions that provided emulsions with higher indexes, it should be noted that the heart extracts at any condition displayed rather poorer emulsifying properties than extracts from porcine spleen, which were reported to achieve EAI values from 244 to $500 \mathrm{~m}^{2} \mathrm{~g}^{-1}$ and ESI values from 57 to $381 \mathrm{~min}$ [11]

Mathematical models for both the emulsifying activity and emulsion stability indexes are shown in Table 5. Emulsion indexes show to be influenced by both $\mathrm{pH}$ and ionic strength, but it is worth noting that the models merely account for $65.5 \%$ and less than $45 \%$ of the data variability for EAI and ESI, respectively. As can be observed from the response surface in Figure $3 d$, heart protein extracts $\left(5 \mathrm{~g} \mathrm{~L}^{-1}\right)$ would exhibit relatively low emulsifying activity at any $\mathrm{pH} / \mathrm{NaCl}$ combination, up to $300-400 \mathrm{~m}^{2} \mathrm{~g}^{-1}$ at best, which is much lower than the capacity to form o:w emulsions of blood proteins [23]. In spite of this, it is important to highlight that the EAI values obtained were similar to those displayed by palm seed protein extracts [42], and even higher than those from ovine whey proteins [43], fish protein extracts [44], yeast proteins, and egg albumins [24].

\subsubsection{Gelling Properties}

Gelation is as a multistage process involving the initial denaturation of native protein structure and unfolding of the protein molecules, followed by aggregation and cross-linking between proteins. Since heating induces protein denaturation, aggregation, and eventually the formation of a gel that gives consistency to the food product, many proteins act as gelling or thickening agents when a thermal treatment is applied [45]. Indeed, one of the important functional properties of muscle proteins is their ability to form a gel. Different contribution to both gel formation and gel characteristics have been reported for sarcoplasmic and myofibrillar proteins. For myofibrillar individual proteins such as myosin and protein complexes such as actomyosin, $\mathrm{pH}$ significantly influences gel formation. Optimal pH for gelation depends on the concentration of myosin and actin in solution. The state of meat protein molecules, which is influenced by the ionic strength, is also important for gelling capacity since gel formation results from protein-protein and protein-solvent interactions [46].

Although salt-soluble muscle proteins are known to contribute primarily to gel formation, their recovery from some organs is difficult due to the high content of connective tissue [7]. All extracts contain myofibrillar proteins, as shown by SDS-PAGE, but their relatively low protein content has probably impaired the heat-induced gel forming ability. Nonetheless, it is interesting to realize (Table 4 and Figure 3f) that some of them displayed heat-induced gelling capacity in spite of their relatively low protein content, which would probably improve after a gentle concentration process. 
Protein extracts at $\mathrm{pH} \leq 5$ and $\mathrm{pH} 8.6$ showed some aggregation after the heat treatment, but they were not able to form consistent gels. On the other hand, self-supporting gels were obtained on heating extracts at $\mathrm{pH}$ 6.5-8, which showed improved firmness with increasing $\mathrm{NaCl}$ concentration. It is worth noting that all heart protein gels obtained in the present work showed high syneresis. Addition of $\mathrm{NaCl}$ has been described as a key requirement for good gelling properties for myofibrillar protein-rich extracts prepared from bovine hearts using a surimi-like process [47]. Tsermoula et al. also reported an increase in gel hardness when $2 \% \mathrm{NaCl}$ was added to the extracts from porcine heart standardized at $8 \%$ protein content [16]. Nevertheless, gel forming ability of water soluble pork liver proteins without salt showed to be higher compared to high salt concentrations [29]. It seems interesting to highlight that extracts able to form firm gels somewhat coincide with the ones showing the band in the range $25-30 \mathrm{kDa}$ of their electrophoretic profile, which supposedly could correspond to several blood globulins. Gelation studies on blood proteins reported that the development of strong gels in a wide range of $\mathrm{pH}$ was mainly attributed to the globulins fraction that were also responsible for the strength of gels when mixed with albumin [23,48]. Likewise, Steen et al. observed that higher salt concentrations shifted onset gelation temperature to lower temperatures [29].

The mathematical model obtained (Table 5) fits well to the experimental data $\left(R^{2}=0.946\right)$ and confirms the strong dependence of the gelling capacity on the ionic strength, as well as its interaction with the $\mathrm{pH}$. As can be seen in Figure $3 \mathrm{f}$, the effect of $\mathrm{pH}$ is only important when the extraction process is carried out with buffers with high $\mathrm{NaCl}$ content. Higher gel firmness values correspond to solutions at $\mathrm{pH} 6-7.5$, showing maximum values at 3-4\% $\mathrm{NaCl}$. At lower $\mathrm{NaCl}$ contents, the firmness is reduced in half and becomes practically independent of the $\mathrm{pH}$ factor.

\section{Conclusions}

The protein functional properties strongly depend on the extraction conditions, which affect each property in a different way. Protein extracts showing diverse functionality were obtained from porcine hearts by using different extraction buffers. The conditions that showed both the best extraction yield and the highest protein content were $\mathrm{pH} 8.6$ and $2 \% \mathrm{NaCl}$. Highest foaming capacity and stability corresponded to the solutions extracted with acid buffers. The foam stability improved with increased ionic strength. The highest emulsifying activity was found in solutions at $\mathrm{pH}>6.5$ with low $\mathrm{NaCl}$, whilst the more stable emulsions were obtained at $\mathrm{pH} 8$ and $0.58 \% \mathrm{NaCl}$; nevertheless, heart protein extracts showed rather poorer emulsifying properties than extracts from other porcine organs. Although protein extracts at $\mathrm{pH} \leq 5$ and $\mathrm{pH} 8.6$ were not able to form consistent gels, self-supporting gels were obtained from extracts at $\mathrm{pH} 6.5-8$, all showing enhanced firmness as $\mathrm{NaCl}$ concentration increases.

Response surface methodology has been used successfully to systematically study the effects of extraction conditions on the recovery and functionality of soluble proteins from porcine hearts. The mathematical models obtained allow for knowing the variables that influence every functional property and their interactions, and also to determine the best conditions to obtain ingredients with a specific functionality. Therefore, these models can be used to foreknow the most suitable operating conditions according to the intended use of the protein extracts.

Recovering technofunctional proteins for food applications from industrial byproducts would contribute to improving the sustainability of the meat industry.

Author Contributions: Each author has made substantial contributions to the present work and has approved the submitted version. Their individual contributions follow: conceptualization, D.P., M.T., and C.C.; methodology, D.P., M.T., and E.S.; investigation, D.P., E.C., and J.G.; data curation and interpretation, D.P., M.T., E.C., J.G., E.S., and C.C.; writing, D.P. (original draft preparation), M.T., E.S., and C.C. (review and editing); supervision and project administration, C.C. All authors have read and agreed to the published version of the manuscript.

Funding: This research was funded by Government of Catalonia, grant number 56.21.031.2016 3A.

Acknowledgments: This work was supported by the industrial abattoirs: Patel SAU, Olot Meats SA, Friselva SA, Frigorifics del Nordeste SA, and Frigorífics Costa Brava SA. We acknowledge A.M. Aymerich and NORFRISA (Girona, Spain) for the helpful technical assistance and for kindly donation of heart samples, respectively. 
Conflicts of Interest: The authors declare no conflict of interest.

\section{References}

1. Jayathilakan, K.; Sultana, K.; Radhakrishna, K.; Bawa, A.S. Utilization of byproducts and waste materials from meat, poultry and fish processing industries: A review. J. Food Sci. Technol. 2012, 49, 278-293. [CrossRef]

2. Rivera, J.A.; Sebranek, J.G.; Rust, R.E. Functional properties of meat by-products and mechanically separated chicken (MSC) in a high-moisture model petfood system. Meat Sci. 2000, 55, 61-66. [CrossRef]

3. Toldrá, F.; Aristoy, M.C.; Mora, L.; Reig, M. Innovations in value-addition of edible meat by-products. Meat Sci. 2012, 92, 290-296. [CrossRef] [PubMed]

4. Toldrá, F.; Mora, L.; Reig, M. New insights into meat by-product utilization. Meat Sci. 2016, 120, 54-59. [CrossRef] [PubMed]

5. Toldrá, F.; Reig, M. Innovations for healthier processed meats. Trends Food Sci. Technol. 2011, 22,517-522. [CrossRef]

6. Zhang, W.; Xiao, S.; Samaraweera, H.; Lee, E.J.; Ahn, D.U. Improving functional value of meat products. Meat Sci. 2010, 86, 15-31. [CrossRef]

7. Lynch, S.A.; Mullen, A.M.; O’Neill, E.; Drummond, L.; Álvarez, C. Opportunities and perspectives for utilisation of co-products in the meat industry. Meat Sci. 2018, 144, 62-73. [CrossRef]

8. Matak, K.E.; Tahergorabi, R.; Jaczynski, J. A review: Protein isolates recovered by isoelectric solubilization/precipitation processing from muscle food by-products as a component of nutraceutical foods. Food Res. Int. 2015, 77, 697-703. [CrossRef]

9. Mullen, A.M.; Álvarez, C.; Zeugolis, D.I.; Henchion, M.; O’Neill, E.; Drummond, L. Alternative uses for co-products: Harnessing the potential of valuable compounds from meat processing chains. Meat Sci. 2017, 132, 90-98. [CrossRef]

10. Papier, K.; Ahmed, F.; Lee, P.; Wiseman, J. Stress and dietary behaviour among first-year university students in Australia: Sex differences. Nutrition 2015, 31, 324-330. [CrossRef]

11. Toldrà, M.; Parés, D.; Saguer, E.; Carretero, C. Recovery and Extraction of Technofunctional Proteins from Porcine Spleen Using Response Surface Methodology. Food Bioprocess Technol. 2019, 12, 298-312. [CrossRef]

12. Zouari, N.; Fakhfakh, N.; Amara-Dali, W.B.; Sellami, M.; Msaddak, L.; Ayadi, M.A. Turkey liver: Physicochemical characteristics and functional properties of protein fractions. Food Bioprod. Process. 2011, 89, 142-148. [CrossRef]

13. Kim, Y.H.; Cheong, J.K.; Yang Sungnam, S.Y.; Lee Suwon, M.H. Functional properties of the porcine variety meats. Korean J. Anim. Sci. 1991, 33, 507-514.

14. Nuckles, R.O.; Smith, D.M.; Merkel, R.A. Meat By-product protein composition and functional properties in model systems. J. Food Sci. 1990, 55, 640-643. [CrossRef]

15. Kim, H.K.; Ha, S.J.; Kim, Y.H.; Hong, S.P.; Kim, Y.U.; Song, K.M.; Lee, N.H.; Jung, S.K. Protein extraction from porcine myocardium using ultrasonication. J. Food Sci. 2017, 82, 1059-1065. [CrossRef]

16. Tsermoula, P.; Virgili, C.; Ortega, R.G.; Mullen, A.M.; Álvarez, C.; O’Brien, N.M.; O’Flaherty, E.A.A.; $\mathrm{O}^{\prime} \mathrm{Neill}, \mathrm{E} . \mathrm{E}$. Functional protein rich extracts from bovine and porcine hearts using acid or alkali solubilisation and isoelectric precipitation. Int. J. Food Sci. Technol. 2019, 54, 1292-1298. [CrossRef]

17. International Organization for Standardization. Microbiology of the Food Chain. Horizontal Method for the Enumeration of Microorganisms_Part 1: Colony Count at $30^{\circ} \mathrm{C}$ by the Pour Plate Technique; Standard No. 4833-1:2013; International Organization for Standardization: Geneva, Switzerland, 2013.

18. Association of Official Analytical Chemists (AOAC). Official Methods of Analysis of AOAC; Association of Analytical Communities: Gaithersburg, MD, USA, 2000.

19. International Organization for Standardization. Determination of Nitrogen Content. International Standards Meat and Meat Products; Standard No. 93:1978; International Organization for Standardization: Geneva, Switzerland, 1978.

20. Kolar, K. Colorimetric determination of hydroxyproline as measure of collagen content in meat and meat products: NMKL collaborative study. J. AOAC 1990, 73, 54-57. [CrossRef]

21. International Organization for Standardization. Determination of Total Fat Content. International Standards Meat and Meat Products; Standard No. 1443:1973; International Organization for Standardization: Geneva, Switzerland, 1973. 
22. Fort, N.; Kerry, J.P.; Carretero, C.; Kelly, A.L.; Saguer, E. Cold storage of porcine plasma treated with microbial transglutaminase under high pressure. Effects on its heat-induced gel properties. Food Chem. 2009, 115, 602-608. [CrossRef]

23. Dàvila, E.; Saguer, E.; Toldrà, M.; Carretero, C.; Parés, D. Surface functional properties of blood plasma protein fractions. Eur. Food Res. Technol. 2007, 226, 207-214. [CrossRef]

24. Pearce, K.N.; Kinsella, J.E. Emulsifying properties of proteins-Evaluation of a turbidimetric technique. J. Agric. Food Chem. 1978, 26, 716-723. [CrossRef]

25. Parés, D.; Ledward, D.A. Emulsifying and gelling properties of porcine blood plasma as influenced by high-pressure processing. Food Chem. 2001, 74, 139-145. [CrossRef]

26. Seong, P.N.; Park, K.M.; Cho, S.H.; Kang, S.M.; Kang, G.H.; Park, B.Y.; Moon, S.S.; Van Ba, H. Characterization of edible pork by-products by means of yield and nutritional composition. Korean J. Food Sci. Anim. Res. 2014, 34, 297-306. [CrossRef] [PubMed]

27. Kang, G.; Seong, P.; Moon, S.; Cho, S.; Ham, H.; Park, K.; Kang, S.; Park, B. Distribution Channel and Microbial Characteristics of Pig By-products in Korea. Korean J. Food Sci. 2014, 34, 792-798. [CrossRef] [PubMed]

28. European Food Safety Authority (EFSA). Commission regulation (EC) no 2073/2005 of 15th November 2005 on microbiological criteria for foodstuffs. Off. J. Eur. Union 2005, 338, 1-26.

29. Steen, L.; Glorieux, S.; Goemaere, O.; Brijs, K.; Paelinck, H.; Foubert, I.; Fraeye, I. Functional properties of pork liver protein fractions. Food Bioprocess Technol. 2016, 9, 970-980. [CrossRef]

30. Selmane, D.; Christophe, V.; Gholamreza, D. Extraction of proteins from slaughterhouse by-products: Influence of operating conditions on functional properties. Meat Sci. 2008, 79, 640-647. [CrossRef] [PubMed]

31. Hrynets, Y.; Omana, D.A.; Xu, Y.; Betti, M. Effect of acid- and alkaline-aided extractions on functional and rheological properties of proteins recovered from mechanically separated turkey meat (MSTM). J. Food Sci. 2010, 75, 477-486. [CrossRef]

32. Krasnowska, G.; Gorska, I.; Gergont, J. Evaluation of functional properties of offal proteins. Meat Sci. 1995, 39, 149-155. [CrossRef]

33. Pérez-Chabela, M.L.; Soriano-Santos, J.; Ponce-Alquicira, E.; Díaz-Tenorio, L.M. Electroforesis en gel de poliacrilamida-SDS como herramienta en el estudio de las proteínas miofibrilares. Nacameh 2015, 9, 77-96.

34. Howell, N.K.; Lawrie, R.A. Functional aspects of blood plasma proteins I. Separation and characterization. J. Food Technol. 1983, 18, 747-762. [CrossRef]

35. Luna, E.J.; Hitt, A.L. Cytoskeleton-plasma membrane interactions. Science 1992, 258, $955-964$. [CrossRef] [PubMed]

36. Grujić, R.; Savanović, D. Analysis of myofibrillar and sarcoplasmic proteins in pork meat by capillary gel electrophoresis. Foods Raw Mater. 2018, 6, 421-428. [CrossRef]

37. Toldrà, M.; Parés, D.; Saguer, E.; Carretero, C. Hemoglobin hydrolysates from porcine blood obtained through enzymatic hydrolysis assisted by high hydrostatic pressure processing. Innov. Food Sci. Emerg. Technol. 2011, 12, 435-442. [CrossRef]

38. Aluko, R.E.; McIntosh, T. Polypeptide profile and functional properties of defatted meals and protein isolates of canola seeds. J. Sci. Food Agric. 2001, 81, 391-396. [CrossRef]

39. Indrawati, L.; Wang, Z.; Narsimhan, G.; Gonzalez, J. Effect of processing parameters on foam formation using a continuous system with a mechanical whipper. J. Food Eng. 2008, 88, 65-74. [CrossRef]

40. Yang, Q.L.; Lou, X.W.; Wang, Y.; Pan, D.D.; Sun, Y.Y.; Cao, J.X. Effect of pH on the interaction of volatile compounds with the myofibrillar proteins of duck meat. Poultry Sci. 2017, 96, 1963-1969. [CrossRef]

41. Lynch, S.A.; Álvarez, C.; O’Neill, E.E.; Keenan, D.F.; Mullen, A.M. Optimization of protein recovery from bovine lung by $\mathrm{pH}$ shift process using response surface methodology. J. Sci. Food Agric. 2018, 98, 1951-1960. [CrossRef]

42. Akasha, I.; Campbell, L.; Lonchamp, J.; Euston, S.R. The major proteins of the seed of the fruit of the date palm (Phoenix dactylifera L.): Characterisation and emulsifying properties. Food Chem. 2016, 197, 799-806. [CrossRef]

43. Díaz, O.; Pereira, C.D.; Cobos, A. Functional properties of ovine whey protein concentrates produced by membrane technology after clarification of cheese manufacture by-products. Food Hydrocoll. 2004, 18, 601-610. [CrossRef]

44. Liceaga-Gesualdo, A.M.; Li-Chan, E.C.-Y. Functional Properties of Fish Protein Hydrolysate from Herring (Clupea harengus). J. Food Sci. 1999, 64, 1000-1004. [CrossRef] 
45. Ziegler, G.R.; Foegeding, E.A. The gelation of proteins. Adv. Food Nutr. Res. 1990, 34, 203-298.

46. Zayas, J.F. Gelling Properties of proteins. In Functionality of Proteins in Food; Springer: Berlin/Heidelberg, Germany, 1997; pp. 310-366.

47. James, J.M.; Mireles DeWitt, C.A. Gel Attributes of Beef Heart When Treated by Acid Solubilization Isoelectric Precipitation. J. Food Sci. 2004, 69, 473-480. [CrossRef]

48. Parés, D.; Saguer, E.; Carretero, C. Blood by-products as ingredients in processed meat. In Processed Meats: Improving Safety, Nutrition and Quality; Kerry, J.P., Kerry, J.F., Eds.; Woodhead Publishing Ltd.: Cambridge, UK, 2011; pp. 218-242.

Publisher's Note: MDPI stays neutral with regard to jurisdictional claims in published maps and institutional affiliations.

(C) 2020 by the authors. Licensee MDPI, Basel, Switzerland. This article is an open access article distributed under the terms and conditions of the Creative Commons Attribution (CC BY) license (http://creativecommons.org/licenses/by/4.0/). 